\title{
Philodendron luisae (Araceae), a new species from Rio de Janeiro State, Brazil
}

\author{
Luana Silva Braucks Calazans ${ }^{*}$, Nerivaldo Gomes Antas $^{2}$ and Cassia Mônica Sakuragui ${ }^{1}$
}

\begin{abstract}
Background: Philodendron is the second largest genus of Araceae, being highly diverse in the Atlantic Forest biome, with nearly one third of the Brazilian species occurring in Southern Brazil, particularly in Rio de Janeiro state. During a local inventory in Silva Jardim municipality, we found a peculiar population of Philodendron growing in lowland rainforest.
\end{abstract}

Results: After morphological analysis and comparisons with similar species, the population proved to be a new undescribed species of subgenus Philodendron section Macrobelium.

Conclusions: The new species, named Philodendron luisae, is here described, illustrated and compared to morphologically close species.

Keywords: Aroids; Taxonomy; Conservation; Atlantic forest; Silva Jardim

\section{Background}

Philodendron Schott is the second largest genus of Araceae, with ca. 480 exclusively Neotropical species (Boyce and Croat 2014). The genus is highly diverse in tropical rainforests, such as the Atlantic Forest of coastal Brazil. Despite the elevated levels of deforestation in the Atlantic Forest (Fundação SOS Mata Atlântica - Instituto Nacional de Pesquisas Espaciais 2014), this biome accounts for ca. $12 \%$ of the genus diversity in its overall range and $40 \%$ of the genus diversity in Brazil (Sakuragui et al. 2014). These numbers are being constantly increased by the recognition of new species, especially from Southeastern Brazil (e.g. Buturi et al. 2014, Calazans and Sakuragui 2013, Coelho 2010, Gonçalves 2011).

In Rio de Janeiro state, Southern Brazil, the genus is represented by an impressive number of species, despite the reduced geographical range and high levels of habitat fragmentation (Sakuragui et al. 2011). Of the 168 Brazilian species, 30 occur in the Rio de Janeiro state (Sakuragui et al. 2014). Although efforts to catalogue the regional flora dates back to the eighteen century, many localities remain poorly known or even uncollected, especially

\footnotetext{
* Correspondence: luanasbcalazans@gmail.com

${ }^{1}$ Instituto de Biologia, Departamento de Botânica, Universidade Federal do Rio de Janeiro, CCS, Av. Carlos Chagas Filho, 373 - Sala A1-088 - Bloco A, Ilha do Fundão, Rio de Janeiro, RJ CEP 21941-902, Brazil

Full list of author information is available at the end of the article
}

outside the metropolitan area of the Rio de Janeiro City, justifying intensive sampling efforts.

Here we describe Philodendron luisae sp. nov., an only recently collected and recognized species from Rio de Janeiro State's lowlands.

\section{Methods}

During a flora inventory conducted in the Atlantic Forest remnants in Silva Jardim municipality, Rio de Janeiro State, we found an indeterminable Philodendron species. It was recognized as belonging to subgenus Philodendron section Macrobelium and analyzed through the two more comprehensive and updated keys of the section (Croat 1997, Sakuragui et al. 2005). The species was also compared with the type specimens and descriptions of morphologically similar species. The descriptive terminology follows Stearn (2004) and Mayo (1991). Morphological analyzes of fresh and dry materials were performed with the aid of a stereoscopic microscope. The extent of occurrence and area of occupancy were calculated using the GeoCAT tool (Bachman et al. 2011).

\section{Results and discussion}

Philodendron luisae Calazans, sp. nov. (Figures 1 and 2).

Type:-BRAZIL. Rio de Janeiro: Silva Jardim, road RJ-126, Sítio Além do Horizonte, $22^{\circ} 32^{\prime} 47.8^{\prime \prime} \mathrm{S}, 42^{\circ}$ 


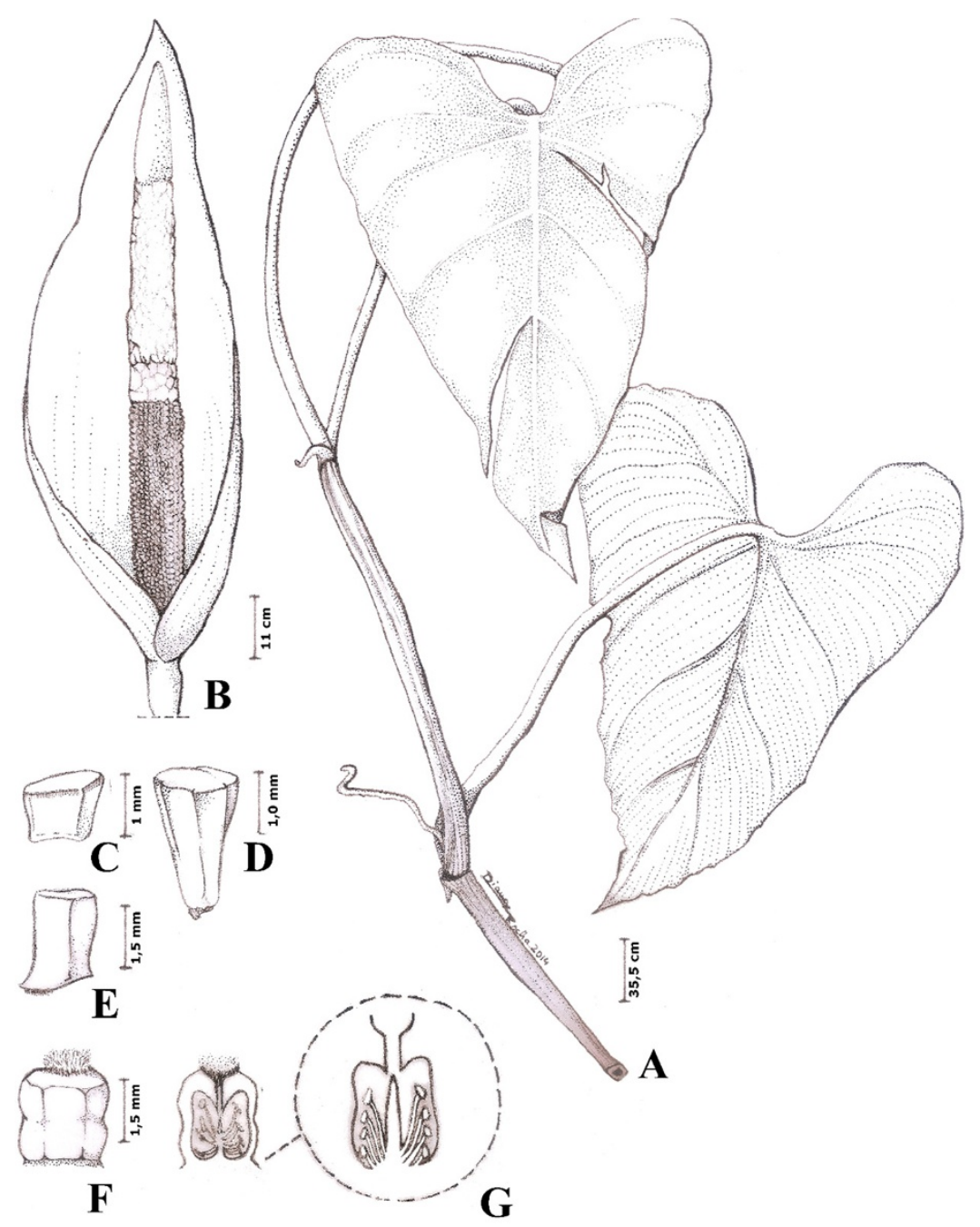

Figure 1 Philodendron luisae. A. Habit, x 1/2. B. Inflorescence, x 1. C. Apical staminode. D. Stamen. E. Itermediate staminode. F. Gynoecium G. Longitudinal cut of gynoecium and the basal placentation (detail). A from Antas et al. 188 (RB); B-G from Antas 181 (RB).

27' 54.1" W, 07 November 2013, N.G. Antas 181 (holotype, RB; isotypes, NY, K).

Herb hemi-epiphytic. Internodes 4.7-11(-15) cm long, usually shorter in flowering shoots, 3-4-angular, keeled, greenish becoming light brown, drying often cracked with rhytidome-like layers; intravaginal squamules up to 3 per node, inconspicuous, deciduous, becoming dark. Prophyll $6.8-10 \times 0.1-1.5 \mathrm{~cm}$, triangular, deciduous, slightly keeled, smooth, yellowish becoming cream, drying brown. Petiole $11-17 \times 0.4-0.6 \mathrm{~cm}$, adaxially flattened, abaxially rounded, glossy green, slightly striated, drying dark brown; leaf blade 16-20 ×9$11.3 \mathrm{~cm}$, triangular to cordate-sagittate, smooth, glossy green, abaxially paler, drying membranous, striated, olive-green, strongly discolorous, margin entire, apex acuminate, acumen 1-2 cm long, sometimes curved, base cordate; anterior division $12-15.5 \mathrm{~cm}$ long, midrib impressed on both faces, drying dark brown, primary lateral veins $3-4$ pairs, arising from midrib at $70^{\circ}, 40^{\circ}$ and $25-35^{\circ}$ angle respectively from the base to the apex, arcuate to margin, impressed on both faces, drying discrete adaxially, dark brown abaxially, secondary veins indistinct, parallel to primary veins, numerous, drying evident on both faces, prominent adaxially; posterior divisions $3.5-5 \mathrm{~cm}$ long, cordate, primary acroscopic veins 2(-3), basal denudation absent. Inflorescence solitary; peduncle $1.52-2.5 \mathrm{~cm}$ long, cylindrical; spathe 10$11 \mathrm{~cm}$ long, ovate, acuminate, acumen ca. $1 \mathrm{~cm}$ long, constriction not evident, externally green becoming cream towards the apex, striated, internally cream, reddish at the base, resin canals internally visible; stipe absent; spadix 8-9 cm long, slender; apical sterile zone $1.3-2.1 \mathrm{~cm}$ long, yellowish; fertile male zone $3-3.6 \mathrm{~cm}$ long, yellowish; intermediate sterile zone $0.6-0.8 \mathrm{~cm}$ long, cream; female zone 3-4.3 cm long, light green; apical staminodes ca. $1 \mathrm{~mm}$ long, prismatic; stamens ca. 

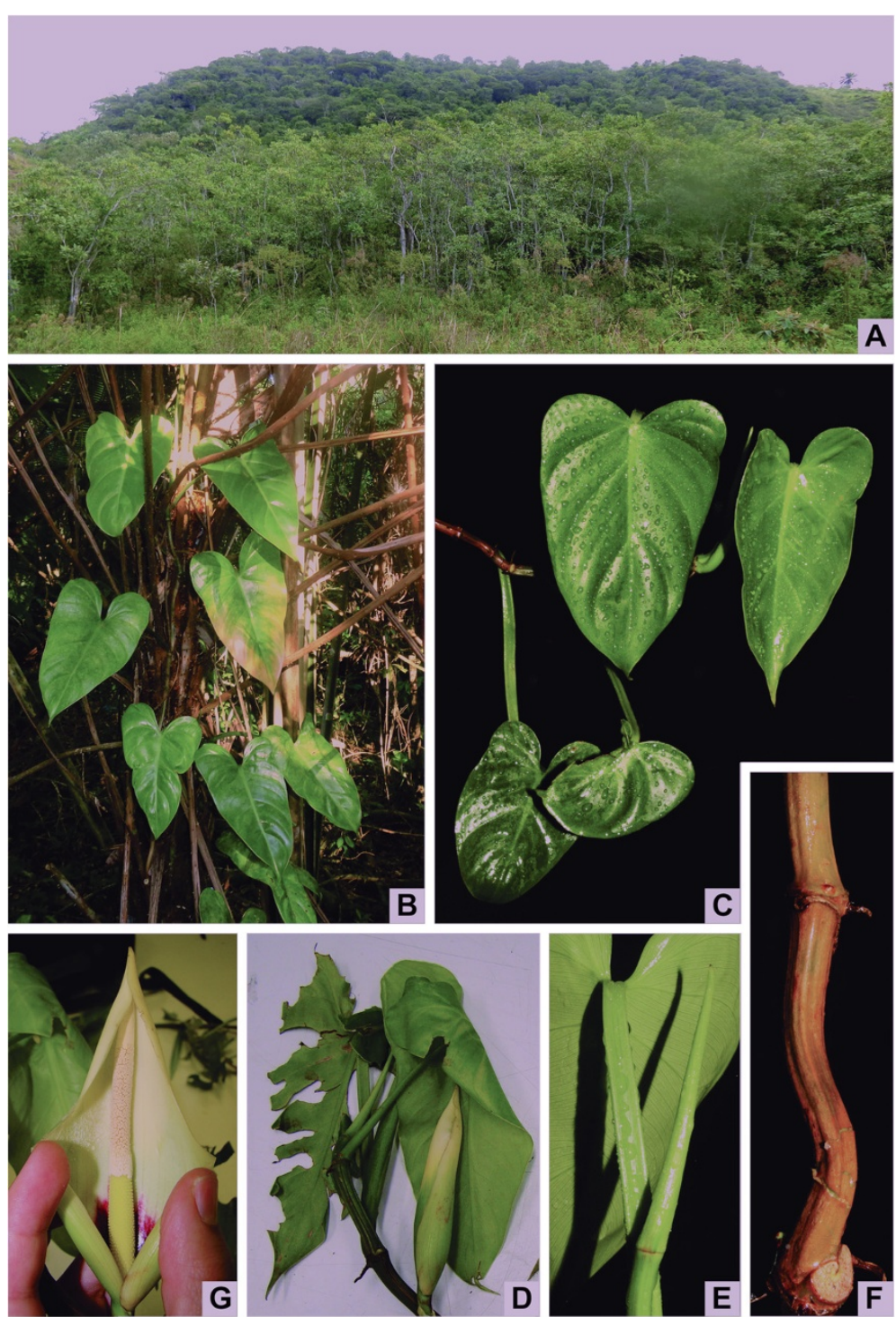

Figure 2 Habitat and morphology of Philodendron luisae. A. Habitat in a fragment of Atlantic Ombrophilous Dense Submontane Forest in Silva Jardim municipality. B. An hemi-epiphytic individual growing on Dicksonia sp. C. Young leaves. D. Flowering shoot with an inflorescence in pre-anthesis and a leaf ripped. E. Detail of the flattened petiole. F. Detail of the angular internodes. G. Detail of the inflorescence manually opened to show the interior.

$1 \mathrm{~mm}$ long, prismatic; intermediate staminodes ca. $1.5 \mathrm{~mm}$ long, prismatic; gynoecium 1.5-2.0 mm long, ovary ca. $1.5 \mathrm{~mm}$ long, barrel-shaped, (6)-7-8-locular, 3-4-ovulate, placentation basal, stylar region ca. $0.75 \mathrm{~mm}$ long, as wide as the ovary, stigmatic region ca. $0.75 \mathrm{~mm}$ long. Berries unknown. Seeds unknown.

\section{Phenology}

Collected in flower in November.

\section{Etymology}

The species is named in memory of the Biology undergraduate student Luisa Pinho Sartori, who inspired the conservation and educational initiatives promoted by Sartori family.

\section{Distribution and ecology}

Only known from three records in reduced Atlantic Ombrophilous Dense Submontane Forest fragments in Silva Jardim municipality, a rural zone of Rio de Janeiro state (Figure 3). The species can be found in small patches of submontane and seasonally flooded forests in areas of regeneration, growing mainly in primary Tabebuia formations associated to the phorophytes Tabebuia cassinoides (Lam.) DC. and Dicksonia sp.. This is indicative of the species' tolerance to open habitats, which may be interesting 


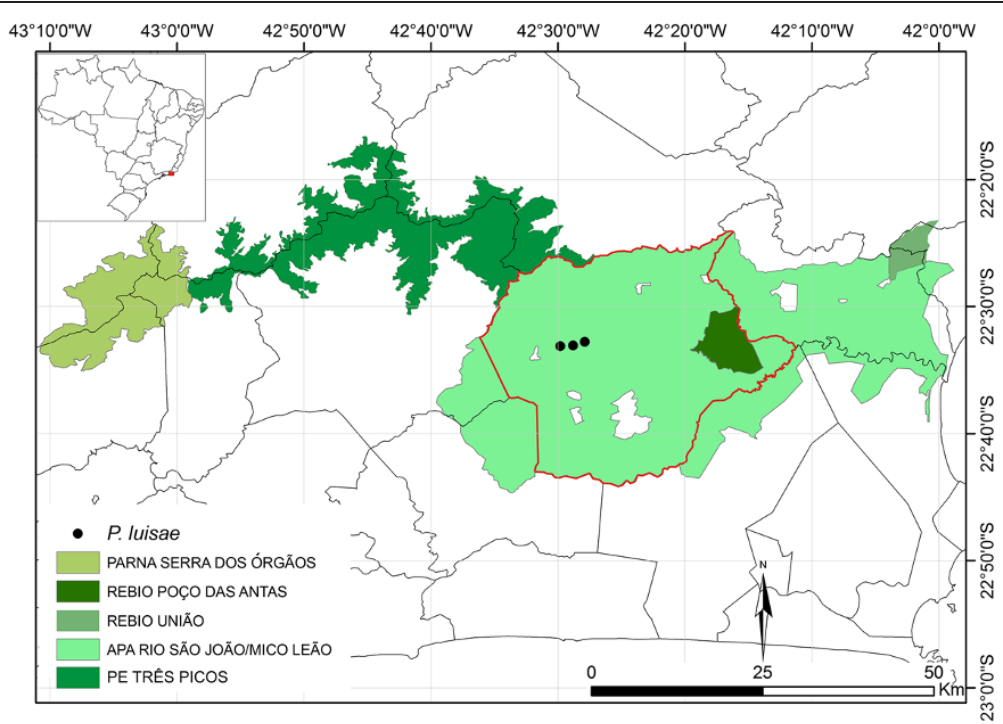

Figure 3 Distribution map of Philodendron luisae. The red spot show the focus area in the Rio de Janeiro state. Green areas represent the ecological corridor Mosaico Central Fluminense composed of different conservation unities. Silva Jardim municipality is highlighted by the red line. APA - Área de Proteção Ambiental; PARNA - Parque Nacional; PE - Parque Estadual; REBIO - Reserva Biológica.

in reforestation projects. The species is also frequently found growing together with P. nadruzianum Sakur.

\section{Conservation}

Our data so far indicate the species as critically endangered (CR) - B1ab (ii, iii, iv) - following the categories and criteria of International Union for Conservation of Nature (2012), with extent of occurrence estimated in $32.2 \mathrm{~km}^{2}$. In this category are inserted species facing a high risk of extinction in the wild, with extent of occurrence $<100 \mathrm{~km}^{2}$ and very fragmented, known from a single location, with continuing decline inferred for the number of individuals and habitat quality.

All records of $P$. luisae up to now are strongly related to stream margins, an area designated as permanently protected by Brazilian federal law in order to preserve the biodiversity and environmental resources in strategic areas. Additionally, the species is only known from particular properties within the Área de Proteção Ambiental da Bacia do Rio São João/ Mico-Leão-Dourado, a conservation unity of sustainable use (Ministério do Meio Ambiente - Instituto Chico Mendes de Conservação da

Table 1 Comparison between $P$. luisae and closely related species

\begin{tabular}{|c|c|c|c|c|c|c|c|c|}
\hline Species & $\begin{array}{l}\text { Internodes } \\
\text { dimension } \\
(\mathrm{cm}) \text { and shape }\end{array}$ & $\begin{array}{l}\text { Extrafloral } \\
\text { nectaries }\end{array}$ & $\begin{array}{l}\text { Leaf } \\
\text { dimension } \\
(\mathrm{cm})\end{array}$ & $\begin{array}{l}\text { Primary } \\
\text { lateral } \\
\text { veins }\end{array}$ & $\begin{array}{l}\text { Inflorescences } \\
\text { per sympodium }\end{array}$ & $\begin{array}{l}\text { Apical } \\
\text { sterile } \\
\text { zone }\end{array}$ & $\begin{array}{l}\text { Spathe color outside, } \\
\text { constriction and } \\
\text { opening at anthesis }\end{array}$ & $\begin{array}{l}\text { Resin canals } \\
\text { inside the } \\
\text { spathe }\end{array}$ \\
\hline P. fragile & $1-5$, terete & absent & $\begin{array}{l}15-37 \times \\
9-24\end{array}$ & $4-5$ & $1(-2)$ & absent & $\begin{array}{l}\text { greenish becoming } \\
\text { cream towards the } \\
\text { apex, slightly constricted, } \\
\text { moderately opened }\end{array}$ & not visible \\
\hline P. luisae & $\begin{array}{l}4.7-11(-15), \\
\text { markedly angular }\end{array}$ & absent & $\begin{array}{l}16-20 \times \\
9-11.3\end{array}$ & $3-4$ & 1 & present & $\begin{array}{l}\text { green becoming cream } \\
\text { towards the apex, not } \\
\text { constricted, moderately } \\
\text { opened }\end{array}$ & visible \\
\hline P. millerianum & 2.4-8.5, terete & absent & $\begin{array}{l}20.2-21.7 \times \\
4-11.1\end{array}$ & 4 & 1 & present & $\begin{array}{l}\text { completely white, } \\
\text { strongly constricted, } \\
\text { slightly opened }\end{array}$ & not visible \\
\hline P. simonianum & 2-4, terete & absent & $\begin{array}{l}36-42 \times \\
14-20\end{array}$ & $3-4$ & $3-4$ & present & $\begin{array}{l}\text { completely white, not } \\
\text { constricted, reflexed }\end{array}$ & not visible \\
\hline P. tenuispadix & 3-4, terete & present & $\begin{array}{l}51-59 \times \\
24-27\end{array}$ & $6-8$ & $1-3$ & present & $\begin{array}{l}\text { completely green, slightly } \\
\text { constricted, almost completely } \\
\text { opened, but not reflexed }\end{array}$ & not visible \\
\hline
\end{tabular}


Biodiversidade 2008). The region suffered historical fragmentation due to selective extraction of timber and farming practices (Carvalho et al. 2006, Guedes-Bruni et al. 2006), however, the forest remnants are very representative of the Atlantic Ombrophilous Dense Submontane Forest, being of high priority for conservation (Carvalho et al. 2006). These remnants compose the ecological corridor Mosaico Central Fluminense along with the conservation units Parque Estadual dos Três Picos, Parque Nacional da Serra dos Órgãos, Reserva Biológica Poço das Antas and Reserva Biológica União (Instituto Estadual do Ambiente 2013) (Figure 3). Probably, populations of $P$. luisae may be found in the lowlands of this ecological corridor, assured within protected areas.

The association between $P$. luisae and the phorophyte $T$. cassinoides is interesting from the conservational viewpoint since this tree is currently threatened and listed in the Red List of the Brazilian Flora (Lohmann et al. 2013). The tree has suffered an intensive selective extraction due to its high quality timber, used mainly for the manufacturing of shoes (Lohmann et al. 2013). This activity probably caused impact on the natural populations of P. luisae in the Tabebuia formation, contributing to the fragmented distribution currently known.

\section{Paratype}

Brazil, Rio de Janeiro: Silva Jardim, road RJ-126, Fazenda Novo Horizonte, $22^{\circ} 33^{\prime}$ 08.0" S, 42 $22^{\prime} 49.6^{\prime \prime}$ W, 13 November 2013, N.G. Antas et al. 188 (MBML, RB, SPF).

\section{Features and affinities}

Philodendron luisae can be promptly recognized by its small and fragile leaves (often ripped when adult) and 3-4-angular, light brown colored stem. The overall leaf shape and inflorescence with apical sterile zone makes this species close to $P$. simonianum Sakur. and P. tenuispadix E.G.Gonç., but it differs by its longer internodes, smaller leaf blade, number of primary lateral veins, number of inflorescences per sympodium, absence of extrafloral nectaries and spathe features (Table 1). When the leaves are still young, $P$. luisae also resembles $P$. fragile Nadruz \& Mayo and P. millerianum Nadruz \& Sakur. by its triangular and fragile leaves without well developed posterior divisions, but the species show a number of differences between them (Table 1).

Moreover, among these related species, $P$. luisae is the unique known to grown in swamp forest, a vegetation formation frequently more open and exposed to seasonality than the humid and shaded forests where the most of Philodendron species occurs.

\section{Conclusions}

Philodendron luisae is a new species easily recognizable and well supported and represents the 31st species record for Rio de Janeiro State. The species, only known from one locality, exemplifies the importance and urgency of local and regional floras to a broaden knowledge of the Brazilian biodiversity.

\section{Competing interests}

The authors declare that they have no competing interests.

\section{Authors' contributions}

LSBC, NGA and CMS collected and discovered the new species; LSBC carried out the morphological analyses; NGA provided the floristic information; all authors prepared, read and approved the final manuscript.

\section{Acknowledgements}

We are grateful to Fábio Sartori for encouraging field expeditions and flora inventories in the Atlantic Forest remnants in his properties, to Diana Rocha Monteiro for the illustration, to Marco Octávio Pellegrini and to Rodrigo

Theófilo Valadares for the assistance with the figures and for suggestions to an earlier version of the manuscript. CMS is a CNPq research fellow.

\section{Author details}

${ }^{1}$ Instituto de Biologia, Departamento de Botânica, Universidade Federal do Rio de Janeiro, CCS, Av. Carlos Chagas Filho, 373 - Sala A1-088 - Bloco A, Ilha do Fundão, Rio de Janeiro, RJ CEP 21941-902, Brazil. 'Fundação Luisa Sartori, Sartori Árvores Nativas e Reflorestamento, Fazenda Além do Horizonte Rodovia RJ-126, km 28, s/n - Gaviões, Silva Jardim, Rio de Janeiro, RJ, Brazil.

Received: 17 September 2014 Accepted: 12 January 2015

Published online: 23 January 2015

\section{References}

Bachman S, Moat J, Hill AW, Torre J, Scott B (2011) Supporting Red List threat assessments with GeoCAT: geospatial conservation assessment tool. ZooKeys 150:117-126

Boyce PC, Croat TB (2014) The Überlist of Araceae: totals for published and estimated number of species in aroid genera. Available via http://www.aroid. org/genera/140601uberlist.pdf. Accessed 14 July 2014

Buturi CV, Temponi LG, Sakuragui CM (2014) A new species of Philodendron (Araceae) in Paraná, Brazil. Phytotaxa 174(3):144-148

Calazans LSB, Sakuragui CM (2013) A new species of Philodendron (Araceae) and a key to Brazilian Atlantic Forest species of $P$. subgenus Pteromischum. Phytotaxa 94(2):49-55

Carvalho FA, Nascimento MT, Braga JMA (2006) Composição e riqueza florística do componente arbóreo da Floresta Atlântica submontana na região de Imbaú, Município de Silva Jardim, RJ. Acta Bot Bras 20(3):727-740

Coelho MAN (2010) Espécies novas de Anthurium e Philodendron (Araceae) do sudeste brasileiro. Bol Mus Biol Mello Leitão (N Ser) 28:21-40

Coelho MAN, Sakuragui CM (2007) A new species of Philodendron Schott (Araceae) from Brazil. Kew Bull 62(4):629-631

Croat TB (1997) A revision of Philodendron subgenus Philodendron (Araceae) for Mexico and Central America. Ann Miss Bot Gard 84(3):311-704

Fundação SOS Mata Atlântica - Instituto Nacional de Pesquisas Espaciais (2014) Atlas dos remanescentes florestais de Mata Atlântica período 2012-2013. ArcPlan, São Paulo

Gonçalves EG (2002) New aroid taxa from Brazil. Aroideana 25:16-35

Gonçalves EG (2011) Philodendron bernardopazii and P. ricardoi spp. nov. (Araceae) from Espírito Santo State, Brazil. Nordic J Bot 29:385-390

Guedes-Bruni RR, Silva Neto SJ, Morim MP, Mantovani W (2006) Composição florística e estrutura de trecho de Floresta Ombrófila Densa Atlântica aluvial na Reserva Biológica de Poço das Antas, Silva Jardim, Rio de Janeiro, Brasil. Rodriguésia 57(3):413-428

Instituto Estadual do Ambiente (2013) Parque Estadual dos Três Picos: plano de manejo. INEA, Rio de Janeiro

International Union for Conservation of Nature (2012) IUCN Red List Categories and Criteria: Version 3.1, 2nd edn. IUCN, Gland and Cambridge

Lohmann LG, Sfair JC, Monteiro NP, Santos Filho LAF (2013) In: Martinelli G, Moraes MA (orgs.) Livro Vermelho da Flora do Brasil, 1st edn. Andrea Jakobsson, Rio de Janeiro

Mayo SJ (1991) A revision of Philodendron subgenus Meconostigma (Araceae). Kew Bull 46(4):601-681 
Ministério do Meio Ambiente - Instituto Chico Mendes de Conservação da Biodiversidade (2008) Plano de manejo da Área de Proteção Ambiental da Bacia do Rio São João/ Mico-Leão-Dourado. MMA, Rio de Janeiro

Sakuragui CM (2001) Two new species of Philodendron (Araceae) from Brazil. Novon 11(1):102-104

Sakuragui CM, Mayo SJ, Zappi DC (2005) Taxonomic revision of Brazilian species of Philodendron section Macrobelium. Kew Bull 60(4):465-513

Sakuragui CM, Calazans LSB, Morais EB, Coelho MAN, Pellegrini MOO (2011)

Diversity and conservation of Philodendron Schott (Araceae) in Atlantic Forest of Rio de Janeiro State, Brazil. Feddes Repert 122(7-8):472-496

Sakuragui CM, Calazans LSB, Soares ML (2014) Philodendron In: Lista de Espécies da Flora do Brasil. Jardim Botânico do Rio de Janeiro. Available via http://www.reflora.jbrj.gov.br/jabot/floradobrasil/FB5015. Accessed 14 July 2014 Stearn WT (2004) Botanical Latin. Timber Press, Portland

\section{Submit your manuscript to a SpringerOpen ${ }^{\circ}$ journal and benefit from:}

- Convenient online submission

- Rigorous peer review

- Immediate publication on acceptance

- Open access: articles freely available online

- High visibility within the field

- Retaining the copyright to your article

Submit your next manuscript at $>$ springeropen.com 